\title{
Ecografía Pediátrica
}

\section{Pediatric Ecography}

\author{
Celia Ferrari $^{1}$ \\ ${ }^{1}$ Médica consultora del Servicio de Diagnóstico por Imágenes HIAEP \\ Sor María Ludovica La Plata, Buenos Aires; Director Médico Adjunto \\ CIMED La Plata, Buenos Aires, Argentina
}

Rev Argent Radiol 2018;82:152.

Esteban Dardanelli, José Lipsich. Ecografía Pediátrica. Buenos Aires: Ediciones Journal

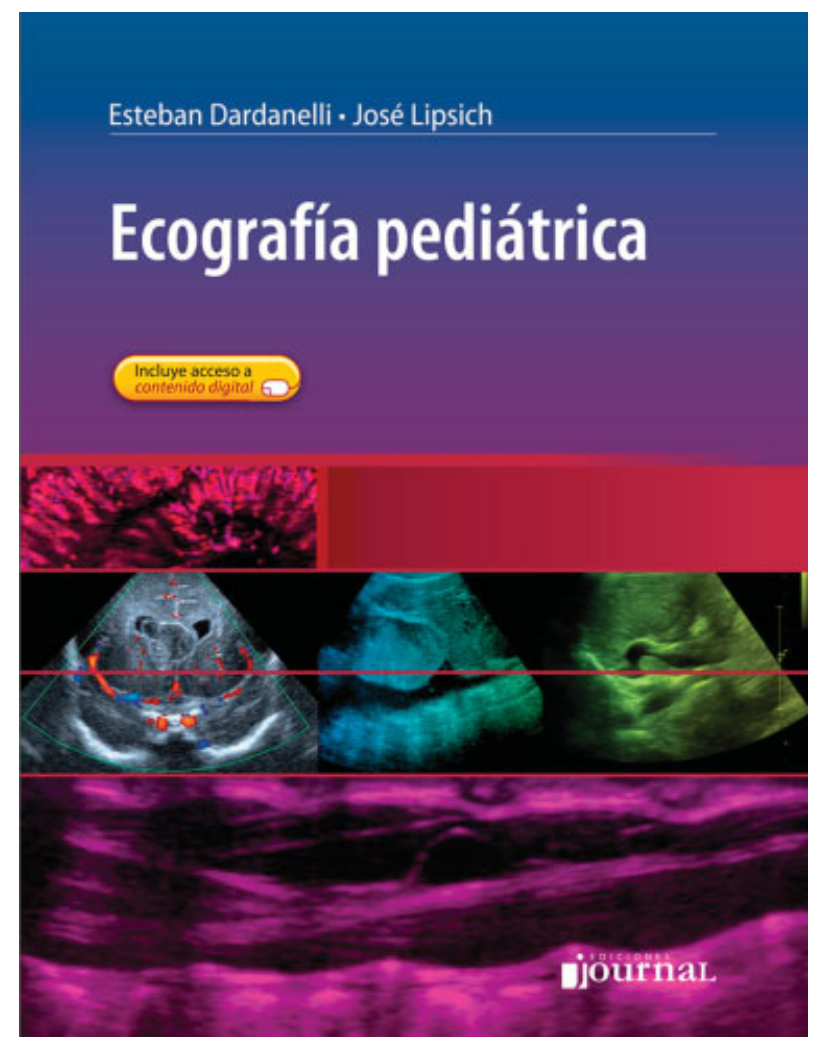

Ecografía Pediátrica es el resultado del trabajo de un equipo que muestra orgulloso la experiencia acumulada durante 30 años en el Servicio de Diagnóstico por Imágenes del Hospital de Pediatría Dr. Juan P. Garrahan.
Address for correspondence Celia Ferrari, MD, Servicio de Diagnóstico por Imágenes HIAEP Sor María Ludovica La Plata, Buenos Aires, Argentina (e-mail: celiaferrari@gmail.com).

Desde su primer capítulo, "Artefactos y Técnica," deslumbra por la claridad de conceptos que hacen la lectura sencilla y llevadera. Continúa en 19 capítulos, cerebro, cara y cuello, tiroides y paratiroides, tórax, cavidad peritoneal y pared abdominal, hígado y vías biliares, bazo, aparato gastrointestinal, glándulas suprarrenales, páncreas y retroperitoneo, riñón y vías urinarias, genitales masculinos y femeninos, sistema musculoesquelético, piel y partes blandas, anomalías vasculares: hemangiomas y malformaciones vasculares, sistema vascular, médula espinal y ecografía intervencionista en pediatría.

Cada capítulo comienza describiendo las técnicas para cada órgano o sistema y la anatomía normal. El desarrollo de las patologías es exhaustivo y muy bien ilustrado con imágenes ecográficas de alta calidad, cualidad que abarca también, a las imágenes adicionales de otros métodos diagnósticos que enriquecen los distintos temas.

Hay coherencia, sin conceptos contradictorios entre los distintos capítulos que refieren a un equipo trabajando amalgamado por una rectoría docente. Los autores cuentan su actividad en la práctica diaria, sin supuestos, sobreentendidos o teorías sin sustento científico, todo es aplicable y accesible, sustentado en la experiencia y en la bibliografía, que es actual y de publicaciones prestigiosas.

Es de destacar la practicidad de los gráficos, las síntesis destacadas del texto y la simplicidad de las tablas. El contenido digital conformado por 11 videos se refiere fundamentalmente al tórax, sería deseable que se extienda a los demás capítulos en la próxima edición.

Ecografía Pediátrica de Ediciones Journal, es un libro útil tanto para el principiante como para el experto. Felicitaciones a los autores Esteban Dardanelli y José Lipsich, este libro es un reflejo de su generosidad para transmitir el conocimiento que galardona aún más su destacada trayectoria. published online July 27, 2018
DOI https://doi.org/

$10.1055 / \mathrm{s}-0038-1661400$. ISSN 1852-9992.
Copyright $\odot$ 2019, Sociedad Argentina de Radiología. Publicado por Thieme Revinter Publicações Ltda., Rio de Janeiro, Brazil. Todos los derechos reservados.

\section{License terms}

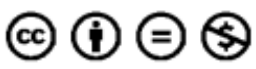

